\title{
Review of Haptic and Computerized (Simulation) Games on Climate Change
}

\author{
Andreas Gerber ${ }^{1(\bowtie)}$, Markus Ulrich ${ }^{2}$, and Patrick Wäger ${ }^{1}$ \\ ${ }^{1}$ Empa, Technology and Society Laboratory, Lerchenfeldstr. 5, \\ 9014 St. Gallen, Switzerland \\ andreas.gerber@empa.ch \\ 2 UCS Ulrich Creative Simulations GmbH, Pfingstweidstr. 31, \\ 8005 Zurich, Switzerland
}

\begin{abstract}
Climate change imposes tremendous, complex challenges on humanity. Thoughtfully designed games can support solving them. This article presents a review of climate games and thereby updates the review conducted by Reckien and Eisenack in 2011. It provides an overview of published climate games and reveals the development of the field over the last years. A total of 119 climate games were found whereof 52 were already part of the review of 2011 . The broad variety of discovered games indicates a lively community and different settings where such tools are being applied. A substantial number of games addressed topics such as international climate conferences, global impacts of global decisions, and effects of individual decisions on their local environment. Other topics, however, were largely absent. They included amongst others - the connection between climate change and health, and games that bride local and global levels. Furthermore, the game types "video games" and "alternate reality games" were not applied frequently. Both, the absent topics and the scarcely used game types open up possibilities to develop the field. Forty-six per cent of the games listed by Reckien and Eisenack seem to have disappeared and could not be found for this review, an observation that may need further attention.
\end{abstract}

Keywords: Climate change $\cdot$ Game $\cdot$ Review $\cdot$ Simulation game $\cdot$ Greenhouse gases $\cdot$ Global warming $\cdot$ Paris agreement $\cdot$ Transition $\cdot$ Climate mitigation Education $\cdot$ Awareness rising $\cdot$ Political action $\cdot$ Creating impact

\section{Introduction}

Climate change imposes tremendous and complex challenges on humanity. Such challenges include the warming of the earth system and its impacts on human and natural systems on different spatial and temporal levels [1]. The Intergovernmental Panel on Climate Change indicates that immediate and drastic mitigation efforts are

Electronic supplementary material The online version of this chapter (https://doi.org/10.1007/ 978-3-030-72132-9_24) contains supplementary material, which is available to authorized users. 
needed to achieving the $1.5{ }^{\circ} \mathrm{C}$ warming target of the Paris Agreement [2], which would imply a fundamental societal transformation [3].

Wrong but common mental models about climate related dynamics are one of several aspects that make it difficult to deal with climate change issues (e.g., $[4,5])$. Because such mental models do not result from poor training in science or an unfamiliarity with climate science, Sterman et al. [6] advise against simply presenting people with more information about climate change. Instead, they propose methods of interactive learning where people experience how complex systems behave and how they can be managed.

Games in general and simulation games in particular are well suited for dealing with complex and interrelated problems, and such tools could be beneficially applied in the context of environmental problems and sustainable development [7]. Reckien and Eisenack [8] emphasize the potential of games to translate scientific results into a language that is understood by the public. Ulrich [9] has identified three major potentials for simulation games to contribute to a sustainable world: embracing time (i.e. making large time spans accessible to first-hand experience), approaching large audiences, and generating real impact. In the context of climate change, games could amongst others - "help to develop confidence and ownership and reduce the fear of the unknown" [10] (p. 27) or enable participants "to experience the benefits of change as well as our ability to be successful" [11] (p. 43). In this context, we apply the term "climate game" for games that explicitly address climate change and/or related topics (e.g. mitigation or adaptation).

The objective of this article is to provide an overview of the development of climate games over the last decades. Accordingly, the paper presents a review of climate games and analyzes specific characteristics of the games such as release year, type, topic and further aspects. The article draws on the previous works of [7] who presented a first overview of simulation games about environmental issues and of Reckien and Eisenack [8] who presented a review of climate games. The application of the same selection criteria as Reckien and Eisenack [8] allowed for tracking and comparing the development of climate games over almost a decade. ${ }^{1}$

The following section of this article, "definitions and methods", introduces the methodological approach in terms of the search process, selection criteria and analysis. The "results" section presents an overview of the games in general, as well as the analysis of selected game characteristics, before the article concludes with the section "discussion and conclusion" that contextualizes the results achieved. A central part of this article is the appendix that lists the games analyzed.

\section{Definitions and Method}

For this review about climate games, the terms "climate game", "climate change game" and "climate related games" were used interchangeably. This reflects the situation in practice, where such games are mostly developed to illustrate one or several aspects

\footnotetext{
${ }^{1}$ The study from Reckien and Eisenack was conducted in 2011, and published in 2013.
} 
related to climate change. As in the review of Reckien and Eisenack [8], games were searched with the two key words "climate" and "game" in English, and "Klima" and "Spiel" in German". To cover a broad variety of games, the following resources were used for the search: the Internet ${ }^{3}$, app platforms for mobile phones, the journal "Simulation \& Gaming", SAGSAGA-newsletter ${ }^{4}$ and personalized communication in the authors' network. The search was conducted from May 2018 until February 2019.

Like the review of Reckien and Eisenack [8], this study focused on "sophisticated" climate games, which meant that the following selection criteria were applied:

- Climate change is an integral aspect of the story line;

- The application shows typical characteristics of a game (e.g. having a goal and offer the player the possibility for interaction);

- The model according to Duke and Geurts [10] (p. 256) is not oversimplified (e.g. simple quizzes were excluded from the review).

As a consequence, applications that were pure simulators or very simple in content were excluded from the review. This also applied to applications without clear focus on climate change, e.g. by exclusively addressing topics such as energy or disaster risk reduction.

For games that matched the selection criteria above, an ad hoc analysis about specific game characteristics was performed. The characteristics included:

- Release year: For most games, it was possible to find out explicitly the release year. In some cases, indirect information had to be used, such as the earliest mentioning in the Internet.

- Type: Considered types were role-play, simulation, online game, video game, board game and other (e.g. alternate reality games).

- Scale: Considered scales were global, several countries, one country, organization/city/community, individual/household, and other (e.g. fictional planet).

- Topic: The topics that games covered were classified into mitigation, politics, impacts/adaptation, energy issues, investment, carbon footprint, insurance, deforestation, disaster risk reduction (DRR), technological change, physics, life quality, and health.

- Language: English or/and German.

- Organization type of the game developers: Private, governmental, nongovernmental and academic organizations.

The next section reports on the outcomes of the analysis in the form of descriptive statistics. The data used can be found in Table S1 "Game Characteristics" in the Supplementary Materials.

\footnotetext{
${ }^{2}$ German was included to allow comparing our results with the Reckien \& Eisenack review.

${ }^{3}$ Google was used as the main search engine. Interesting platforms were, amongst others: www. boardgamegeek.com, www.climateinteractive.org, www.games4sustainability.org, and www.bpb.de.

${ }^{4}$ SAGSAGA: the Swiss Austrian German Simulation and Gaming Association.
} 


\section{Results}

This review identified 119 relevant games. This is a notable increase compared to the 5, and 52 climate-related (simulation) games reported by Ulrich [7], and Reckien and Eisenack [8], respectively. Figure 1 provides the number of games released since 1983. Until 1994, only few games have been released. 1995 was the first year for which more than 1 game per year was found. From 2003 onwards, the number of games released started to increase clearly. In the period 2007-2018, an average of 8 games have been released per year. The annual fluctuations include two peaks in 2009 and 2016 that may reflect the topic's attention because of climate conferences, but essentially seem to be random.

For the period from 1983 to 2010, 60 climate games have been found, in contrast to Reckien and Eisenack [8], who found 50 games for the same period. The difference may be explained by the slightly broader search criteria applied for this review. Twenty-four games listed by Eisenack [8] could not be found anymore. In some cases, traces in the Internet indicate their (prior) existence, and enough information could be gathered to include them in the in-depth analysis presented in the following section. In other cases, however, no traces were found and the games had to be excluded from the in-depth analysis. Furthermore, some games of the 2013 review did not comply with the selection criteria mentioned above. Thus, 24 of the 119 games had to be excluded, leaving 95 games for the in-depth analysis presented below. Examples for excluded games are "Love Letters to the Future", or the "Game Framework for CO2 issue" [12] that did not meet the criteria to be considered a game. A list with the games included in the analysis, and the corresponding links can be found in the appendix. The appendix further lists the games that were part in the review of Reckien and Eisenack [8], however, had to be excluded for the current study, together with the reason for exclusion.

\subsection{Formal Aspects: Type of Developers and Language}

This review distinguishes four types of game developers: academic (universities, research institutions), private (business, consultancy), governmental (authorities), and non-governmental (NGOs). In some cases, institutions from different categories were involved in the development of the same game. These games were assigned to the category that had the most prominent role in its development and application. Private organizations played the most important role in developing climate games (about half of all games), followed by academic institutions, providing one fourth of all games. The remaining parts have been developed by governmental and non-governmental organizations (Fig. 2).

Out of the 95 analyzed games, 70 games were available in English only, 16 games in German only, and 9 in both languages. Some games were available in additional languages, such as French or Japanese. 


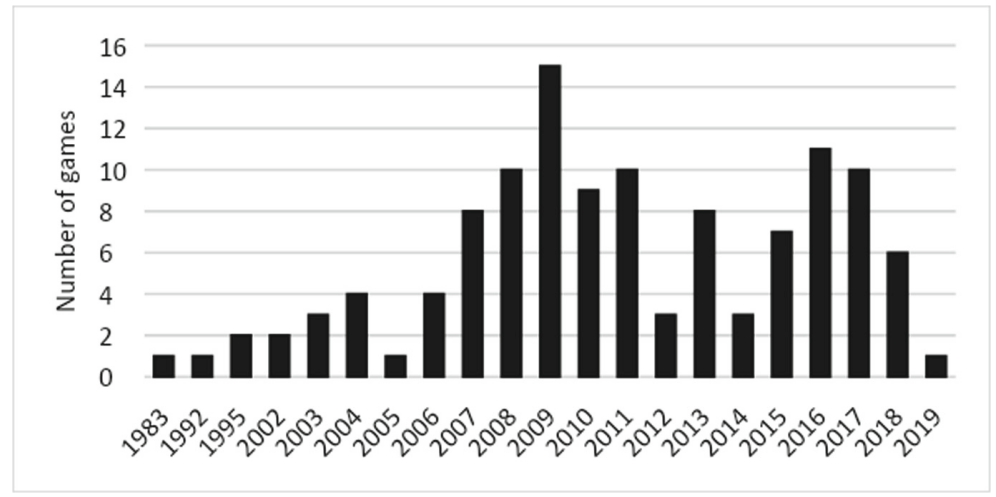

Fig. 1. Number of "sophisticated" climate games released from 1983 to February 2019.

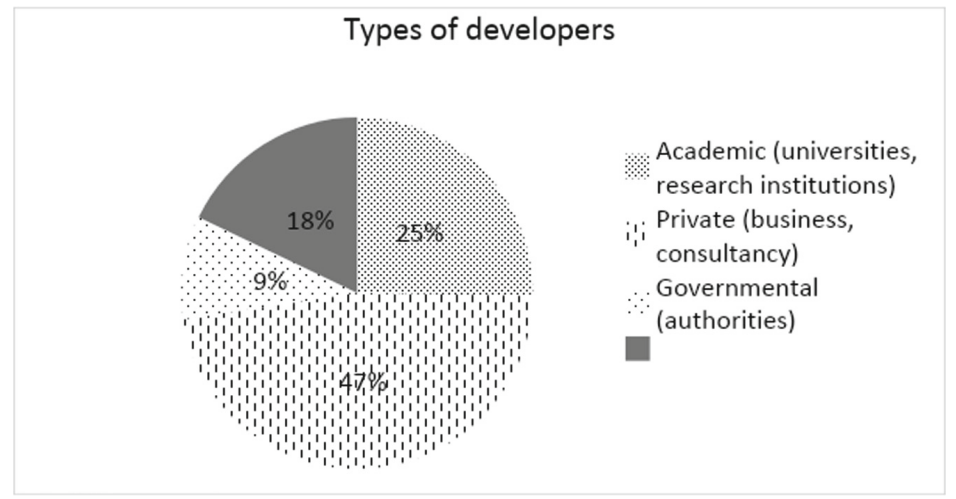

Fig. 2. Share of analyzed climate games by developer categories, $n=95$.

\subsection{Content-Related Aspects: Game Types, Scale and Climate Issues}

The review classified the games in six types (Fig. 3). Many games combined aspects of several types. In such cases, games were classified according to their most dominant type. Role-play games are most prominent, followed by online-games, board games, and simulations. Interestingly, the types "video games" and "augmented reality games" were not common.

Climate change is a global phenomenon, and yet, it is linked to decisions taken on levels down to single individuals. Climate change thus covers a wide range of scales, which are addressed in this review: global, several countries, one country, organization/city/community, individual/household, and other (e.g. fictional planet). "Global", for example, means that players engage in a global issue such as international climate negotiations. Similarly, "one country" means, that players played actors such as ministers that run one country.

The overwhelming part of the analyzed games deals either with global aspects of climate change $(38 \%$, Fig. 4$)$, or with local issues of climate change 


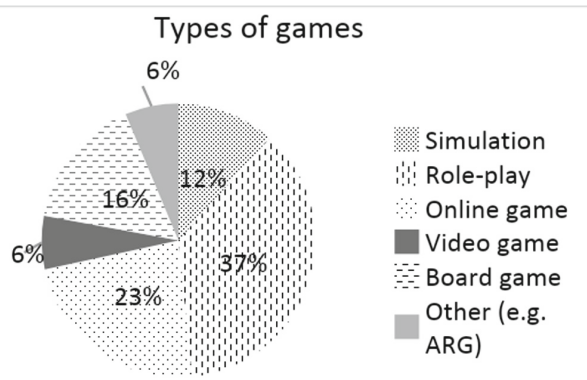

Fig. 3. Share of analyzed climate games of different categories, $n=95$. Note: ARG means "augmented reality game".

(organization/city/community $20 \%$, or individual/household, $22 \%$ ). Scales on country level are rarely addressed (13\%). Out of 95 analyzed games, 8 games (8\%) explicitly covered several scales and thereby connected local with global issues.

The games address a broad variety of climate change related issues (Fig. 5, similar categories as applied by Reckien and Eisenack [8]). Mitigation was the most prominent topic, addressed by $69 \%$ of the games, followed by impacts/adaptation (38\%). Climate politics was addressed by $25 \%$ of the games, which mostly dealt with international climate negotiations. Other common topics in climate games were energy issues, and investment. With one single exception, the topics "health" and "insurance" are almost entirely absent. Physics of climate change is topic in only five games.

\section{Discussion and Conclusion}

The objective of this article was to provide an overview of the development of climate games over the last decades. In a review, 119 relevant games were identified of which 95 were analyzed in more detail. While climate games started to be an issue in 1983, the number of released climate games really took off between 2002 and 2009 and remained on a high level since then. The broad variety of published games indicates a lively community and different settings and topics for which such tools are being applied.

The comparison of the results with the review of Reckien and Eisenack [8] showed the development of climate games since 2011. It is obvious that the number of published games has increased considerably since then. However, 24 games $(46 \%)$ of the games listed in the 2013 review could not be found anymore. In some cases, traces on the Internet, such as entries in game databases, or references in other publications, point to the earlier existence of these games. In other cases, not even traces were found. The disappearance of 24 of 52 games within only 6-9 years is startling. Possible reasons for this could be that these games are outdated, were designed for one-time events, or had a very short lifespan for other reasons. This issue might be worth considering in future studies. 


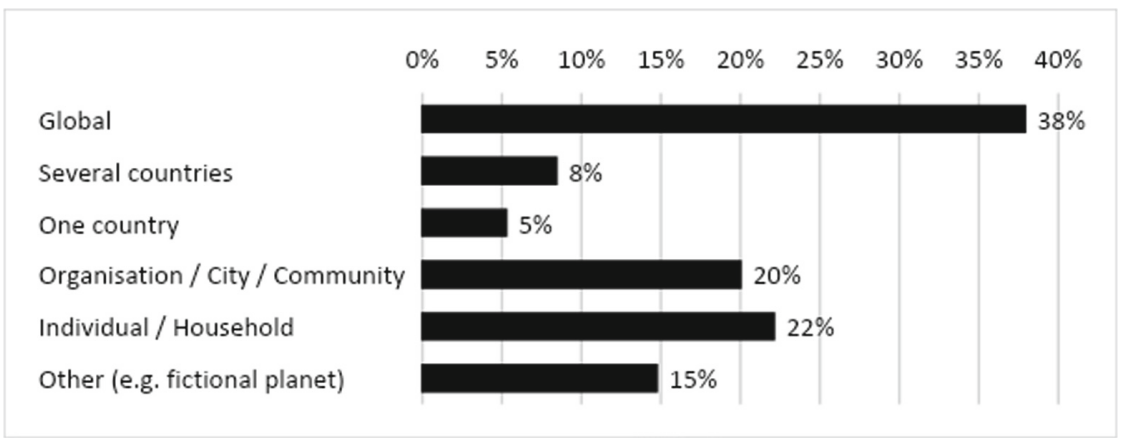

Fig. 4. Scale of issues considered in the selected games. Multiple categories may apply to a single game.

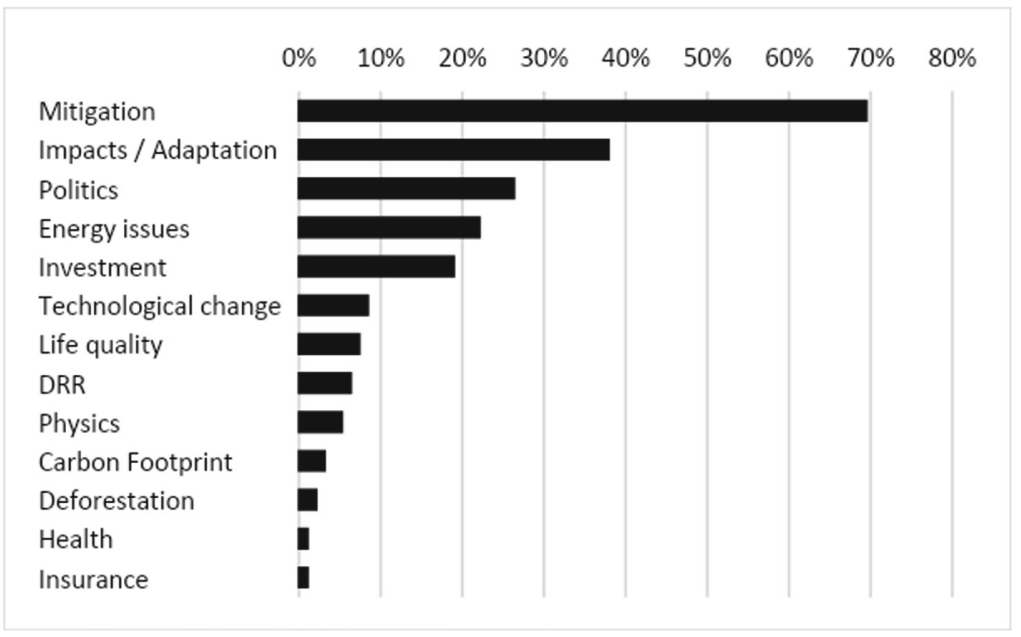

Fig. 5. Issues addressed in the selected games. Multiple categories may apply to a single game. Note: DRR means "disaster risk reduction."

This review analyzed game type, scope and thematic focus of a subset of 95 of the current climate games. In line with the findings of Reckien and Eisenack [8], it has been found that a substantial number of games focuses on one of the following topics: international climate conferences, impacts of global decisions, or effects of individual decisions on their local environment. The most common game types applied were roleplay, board games, simulations and online games. Other possible game types and potential topics, however, were largely absent. Amongst others, those topics and game types include the following:

- IPCC [2] urges for a quick phase-out of all greenhouse gas emissions by 2050 to limit global warming to $1.5^{\circ} \mathrm{C}$, implying a fundamental societal transformation. Nevertheless, very few games explicitly connect the individual or local level to the 
national and global dimensions of climate change and foster transformative literacy on several levels.

- Climate games cover a broad range of relevant topics indicated by IPCC [2]. However, relevant topics such as "health" were addressed only by one game.

- Climate games use "video game" and "augmented reality game" (ARG) formats only to a very limited extent. While video games presumably could reach out to new audiences, ARGs could be used to reach large audiences in an everyday setting, and thereby making a large-scale impact [13].

Many topics are addressed by current climate games and are implemented by applying a variety of game types. Yet, the additional topics and scarcely applied game types mentioned above show a considerable potential for entirely new games that could develop the field and contribute to mitigate and adapt to climate change, as identified by Ulrich [9].

The limitation to German and English excluded a large number of games available in other languages from the review. Not surprisingly, the results show that English clearly is the most important language for climate games, with German games accounting for about a third of English games. The limitation to only two languages limits the comprehensiveness of the results. It might be desirable to include games available in other languages in future reviews.

Acknowledgement. This research was supported by the Swiss National Science Foundation (SNSF) within the framework of the National Research Programme "Sustainable Economy: resource-friendly, future-oriented, innovative" (NRP 73) (grant number 407340_172402). The authors would like to thank all those colleagues and friends within the worldwide network of ISAGA, SAGSAGA and beyond for their valuable hints on existing games in the field of climate change.

Conflicts of Interest. The authors declare no conflict of interest.

\section{Appendix}

List of 95 more sophisticated games used for detailed analysis.

\begin{tabular}{l|l}
\hline Name & Link \\
\hline $2^{\circ}$ und es wird immer heißer & $\begin{array}{l}\text { https://dpsg.de/fileadmin/daten/dokumente/ } \\
\text { Internationale_Gerechtigkeit/planspiel_klima. } \\
\text { pdf }\end{array}$ \\
\hline 2050 Pathways (former my 2050) & $\begin{array}{l}\text { https://www.gov.uk/guidance/2050-pathways- } \\
\text { analysis }\end{array}$ \\
\hline Age of energy & https://www.cityzen-smartcity.eu \\
\hline Before the storm & $\begin{array}{l}\text { https://climatecentre.org/resources-games/ } \\
\text { games/3/before-the-storm }\end{array}$ \\
\hline
\end{tabular}


(continued)

\begin{tabular}{|c|c|}
\hline Name & Link \\
\hline Beyond Paris & $\begin{array}{l}\text { https://www.planpolitik.de/wp-content/uploads/ } \\
\text { 2018/04/planpolitik-Planspieluebersicht-2018- } \\
\text { DE-2.pdf }\end{array}$ \\
\hline Broken cities & $\begin{array}{l}\text { https://www.playistheantidote.com/games/ } \\
\text { broken-cities/ }\end{array}$ \\
\hline Cantor's World & https://fieldsofview.in/projects/cantors-world/ \\
\hline Carbon copy politics & $\begin{array}{l}\text { https://boardgamegeek.com/boardgame/ } \\
\text { 186039/carbon-copy-politics }\end{array}$ \\
\hline Carbon Warfare & $\begin{array}{l}\text { https://www.virtuosgames.com/en/carbon- } \\
\text { warfare }\end{array}$ \\
\hline CEO2 & $\begin{array}{l}\text { https://www.allianz.com/en/press/news/ } \\
\text { commitment/environment/news-2010-05-27. } \\
\text { html }\end{array}$ \\
\hline Clim Way & https://climcity.cap-sciences.net/ \\
\hline Climate Action Game & $\begin{array}{l}\text { https://cafod.org.uk/Education/Secondary-and- } \\
\text { youth-resources/Climate-Action-Game }\end{array}$ \\
\hline Climate Bathtube Simulator & $\begin{array}{l}\text { https://www.cakex.org/tools/climate-bathtub- } \\
\text { simulation }\end{array}$ \\
\hline Climate Challenge (1) & $\begin{array}{l}\text { https://www.bbc.co.uk/sn/hottopics/ } \\
\text { climatechange/climate_challenge/ }\end{array}$ \\
\hline Climate Challenge (2) & https://www.theperspectivitychallenge.org/ \\
\hline Climate Change Showdown & $\begin{array}{l}\text { https://www.bcsea.org/learn/resources-for- } \\
\text { educators/climate-change-showdown/contest }\end{array}$ \\
\hline Climate Defense & $\begin{array}{l}\text { https://www.gamesforchange.org/game/climate- } \\
\text { defense/ }\end{array}$ \\
\hline Climate Diplomat & $\begin{array}{l}\text { https://www.iucnael.org/en/documents/656- } \\
\text { hart-climate-diplomat-negotation/file }\end{array}$ \\
\hline Climate Engineering-Planspiel & $\begin{array}{l}\text { https://www.spp-climate-engineering.de/ce- } \\
\text { planspiel.html }\end{array}$ \\
\hline Climate Game (1) & $\begin{array}{l}\text { https://boardgamegeek.com/boardgame/67996/ } \\
\text { climate-game/credits }\end{array}$ \\
\hline Climate Game (2) & $\begin{array}{l}\text { https://games } 4 \text { sustainability.org/gamepedia/ } \\
\text { climate-game/ }\end{array}$ \\
\hline $\begin{array}{l}\text { Climate Game- Save Earth while having } \\
\text { fun }\end{array}$ & $\begin{array}{l}\text { https://play.google.com/store/apps/details?id= } \\
\text { com.teraception.climatechange }\end{array}$ \\
\hline Climate Health Impact & https://playgen.com/play/climate-health-impact/ \\
\hline Climate Oasis & $\begin{array}{l}\text { https://boardgamegeek.com/boardgame/ } \\
\text { 249405/climate-oasis }\end{array}$ \\
\hline Climate Poker & $\begin{array}{l}\text { https://boardgamegeek.com/boardgame/57422/ } \\
\text { climate-poker }\end{array}$ \\
\hline Climate Quest & $\begin{array}{l}\text { https://play.google.com/store/apps/details?id= } \\
\text { com.EarthGames.ClimateQuest }\end{array}$ \\
\hline Climate-Change Policy Exercise & https://pure.iiasa.ac.at/id/eprint/4937/ \\
\hline
\end{tabular}


(continued)

\begin{tabular}{|c|c|}
\hline Name & Link \\
\hline $\mathrm{Co} 2$ & $\begin{array}{l}\text { https://boardgamegeek.com/boardgame/72225/ } \\
\text { co }\end{array}$ \\
\hline $\mathrm{CO} 2$ peration & https://www.earthspeople.co.uk/projects \\
\hline Connect2climate & https://www.zmqdev.org/connect-2-climate/ \\
\hline Cool it! & https://thepolarhub.org/database/ \\
\hline Cooling down & $\begin{array}{l}\text { https://boardgamegeek.com/boardgame/ } \\
\text { 168555/cooling-down }\end{array}$ \\
\hline D3 Planspiel & $\begin{array}{l}\text { https://www.umweltbundesamt.de/en/ } \\
\text { publikationen/entwicklung-eines-quantitativen- } \\
\text { modells-2 }\end{array}$ \\
\hline d'Aquino and Bah [14] & $\begin{array}{l}\text { Land Policies for Climate Change Adaptation in } \\
\text { West Africa: A Multilevel Companion } \\
\text { Modeling Approach }\end{array}$ \\
\hline Das 3D-Planspiel & $\begin{array}{l}\text { https://www.umweltbundesamt.de/ } \\
\text { publikationen/entwicklung-eines-quantitativen- } \\
\text { modells-2 }\end{array}$ \\
\hline Die Klimaschutzbasis & $\begin{array}{l}\text { https://www.umweltschulen.de/net/nocozwo. } \\
\text { html }\end{array}$ \\
\hline Earth Remembers & https://twitter.com/earthremembers?lang=de \\
\hline Earthers & $\begin{array}{l}\text { https://diary.earthers.studio/2016/10/29/ } \\
\text { theEarthersPitch.html\# }\end{array}$ \\
\hline Ecoego & $\begin{array}{l}\text { https://www.marukin-ad.co.jp/ecoego/ecoego. } \\
\text { html }\end{array}$ \\
\hline Electrocity & https://www.electrocity.co.nz/ \\
\hline Enercities & https://www.enercities.eu/ \\
\hline Energetingen & https://www.energetingen.de/ \\
\hline Energie 21 & $\begin{array}{l}\text { https://boardgamegeek.com/boardgame/16519/ } \\
\text { energie-21 }\end{array}$ \\
\hline Energie für die Zukunft & www.eu-planspiele.de \\
\hline Energie, Klimaschutz und Verbraucher & https://www.ilearning-company.de/ \\
\hline Energy transition game & $\begin{array}{l}\text { https://energytransition.socialsimulations.org/ } \\
\text { en/ }\end{array}$ \\
\hline Energy Wars: Green revolution & $\begin{array}{l}\text { https://play.google.com/store/apps/details?id= } \\
\text { com.gz.EnergyWars }\end{array}$ \\
\hline Europas Klima wandeln! & $\begin{array}{l}\text { https://www.bpb.de/lernen/formate/planspiele/ } \\
\text { 65586/planspiele-detailseite?planspiel_id=166 }\end{array}$ \\
\hline Fate of the world & https://www.soothsayergames.com/ \\
\hline Flood Resilience Game & https://floodresilience.socialsimulations.org/ \\
\hline Future Delta 2.0 & https://futuredelta2.ca/ \\
\hline Gender and Climate Game & $\begin{array}{l}\text { https://www.climatecentre.org/resources- } \\
\text { games/games/9/gender-and-climate-game }\end{array}$ \\
\hline
\end{tabular}


(continued)

\begin{tabular}{|c|c|}
\hline Name & Link \\
\hline Globalisierung und Global Governance & $\begin{array}{l}\text { https://www.planpolitik.de/de/pdf/planspiel_ } \\
\text { globalisierung.pdf }\end{array}$ \\
\hline Go2Zero & https://www.cityzen-smartcity.eu \\
\hline $\begin{array}{l}\text { Greenhouse Emissions Reduction Role- } \\
\text { Play Exercise }\end{array}$ & $\begin{array}{l}\text { https://www.climate.gov/teaching/resources/ } \\
\text { greenhouse-emissions-reduction-role-play- } \\
\text { exercise }\end{array}$ \\
\hline Greenhouse gas game & $\begin{array}{l}\text { https://www.climatecentre.org/resources- } \\
\text { games/games/14/greenhouse-gas-game }\end{array}$ \\
\hline Greenify & Lee, Ceyhan, Jordan-Cooley, and Sung [19] \\
\hline Grönlands Gier & $\begin{array}{l}\text { https://www.planet-schule.de/fileadmin/dam_ } \\
\text { media/wdr/klimawandel/pdf/AB5_Planspiel_ } \\
\text { Klimakonferenz.pdf }\end{array}$ \\
\hline Imagine Earth & https://www.imagineearth.info/ \\
\hline $\begin{array}{l}\text { Increasing Climate Change Resilience of } \\
\text { Urban Poor Communities in Asia-Pacific }\end{array}$ & $\begin{array}{l}\text { https://www.ipa-netzwerk.de/portfolio/ } \\
\text { simulation-game-increasing-climate-change- } \\
\text { resilience-of-urban-poor-communities-in-asia- } \\
\text { pacific }\end{array}$ \\
\hline $\begin{array}{l}\text { Interactive Energy and Climate } \\
\text { Simulation }\end{array}$ & $\begin{array}{l}\text { https://tropicsu.org/interactive-energy-and- } \\
\text { climate-simulation-game/ }\end{array}$ \\
\hline Invest in the future & $\begin{array}{l}\text { https://www.climatecentre.org/resources- } \\
\text { games/games/7/invest-in-the-future }\end{array}$ \\
\hline Keep Cool & $\begin{array}{l}\text { https://www.climate-game.net/keep-cool- } \\
\text { brettspiel/ }\end{array}$ \\
\hline Keep Cool Online & $\begin{array}{l}\text { https://www.climate-game.net/keep-cool-mobil- } \\
2 /\end{array}$ \\
\hline $\begin{array}{l}\text { Klimakonferenz - Internationale } \\
\text { Klimapolitik }\end{array}$ & $\begin{array}{l}\text { https://www.planpolitik.de/de/pdf/planspiel_ } \\
\text { klima.pdf }\end{array}$ \\
\hline KRAFLA & https://www.umweltschulen.de/krafla/ \\
\hline $\begin{array}{l}\text { Lebel, Sriyasak, Kallayanamitra, } \\
\text { Duangsuwan, and Lebel [15] }\end{array}$ & $\begin{array}{l}\text { Learning about climate-related risks: decisions } \\
\text { of Northern Thailand fish farmers in a role- } \\
\text { playing simulation game }\end{array}$ \\
\hline $\begin{array}{l}\text { Let's Negotiate! - Simulation of the } \\
\text { Climate Change Conference }\end{array}$ & $\begin{array}{l}\text { https://www.pacs.ovgu.de/fkf_media/ } \\
\text { Downloads/Berichte/Bericht+Planspiel } \\
\text { +Oktober+2016.pdf }\end{array}$ \\
\hline Losing the Lake & $\begin{array}{l}\text { https://sensor.nevada.edu/nccp/Education/ } \\
\text { Losing\%20the\%20Lake/Default.aspx }\end{array}$ \\
\hline Mobility & https://www.umweltspiele.eu/mobility.htm \\
\hline $\begin{array}{l}\text { Model United Nations with climate } \\
\text { engineering }\end{array}$ & Matzner and Herrenbrück [20] \\
\hline New Shores & https://newshores.socialsimulations.org/ \\
\hline Operation Climate Control & $\begin{array}{l}\text { https://www.climateinteractive.org/policy- } \\
\text { exercises-and-serious-games/19-climate-games- } \\
\text { that-could-change-the-future/ }\end{array}$ \\
\hline
\end{tabular}


(continued)

\begin{tabular}{|c|c|}
\hline Name & Link \\
\hline Paying for Predictions & $\begin{array}{l}\text { https://www.climatecentre.org/resources- } \\
\text { games/games/2/paying-for-predictions }\end{array}$ \\
\hline Peak Oil & $\begin{array}{l}\text { https://boardgamegeek.com/boardgame/ } \\
\text { 169215/peak-oil }\end{array}$ \\
\hline Planspiel zur UN-Klimakonferenz COP21 & $\begin{array}{l}\text { https://www.kas.de/veranstaltungsberichte/ } \\
\text { detail/-/content/planspiel-zur-un- } \\
\text { klimakonferenz-cop21 }\end{array}$ \\
\hline Polar Eclipse & https://www.polareclipsegame.com/ \\
\hline $\begin{array}{l}\text { Simulation of International Climate } \\
\text { Regime Formation }\end{array}$ & Kauneckis and Auer [18] \\
\hline Sinking island & $\begin{array}{l}\text { https://www.climatecentre.org/resources- } \\
\text { games/games/19/sinking-island }\end{array}$ \\
\hline Solar city & $\begin{array}{l}\text { https://boardgamegeek.com/boardgame/ } \\
\text { 248182/solar-city }\end{array}$ \\
\hline Stabilization Wedges Game & https://cmi.princeton.edu/wedges/game \\
\hline Stop Disasters! & https://www.stopdisastersgame.org/ \\
\hline Susclime & $\begin{array}{l}\text { https://journals.sagepub.com/doi/abs/10.1177/ } \\
1046878198292006\end{array}$ \\
\hline Sustainable Delta & $\begin{array}{l}\text { https://www.deltares.nl/en/software/sustainable- } \\
\text { delta-game/ }\end{array}$ \\
\hline The Adventures of Carbon Bond & $\begin{array}{l}\text { Feldpausch-Parker, O'Byrne, Endres, and } \\
\text { Peterson [17] }\end{array}$ \\
\hline trico2lor & https://ucs.ch/ref/reftrico2lor.html \\
\hline UrbanClimateArchitect & https://www.clisap.de/stadtklimaarchitekt/ \\
\hline V GAS & $\begin{array}{l}\text { https://www.climateinteractive.org/policy- } \\
\text { exercises-and-serious-games/19-climate-games- } \\
\text { that-could-change-the-future/ }\end{array}$ \\
\hline $\begin{array}{l}\text { Valkering, van der Brugge, Offermans, } \\
\text { Haasnoot, and Vreugdenhil [16] }\end{array}$ & $\begin{array}{l}\text { A Perspective-Based Simulation Game to } \\
\text { Explore Future Pathways of a Water-Society } \\
\text { System Under Climate Change }\end{array}$ \\
\hline War game: clut and climate change & $\begin{array}{l}\text { https://www.cnas.org/events/war-game-clout- } \\
\text { and-climate-change }\end{array}$ \\
\hline $\begin{array}{l}\text { Was kostet die Welt: Gemeinsam gegen } \\
\text { den Klimawandel? }\end{array}$ & $\begin{array}{l}\text { https://www.hausrissen.org/zielgruppen/ } \\
\text { jugendbildung/41-nachhaltige-klima-und- } \\
\text { energiepolitik.html }\end{array}$ \\
\hline Winds of change & $\begin{array}{l}\text { https://boardgamegeek.com/boardgame/23973/ } \\
\text { winds-change }\end{array}$ \\
\hline World Climate & $\begin{array}{l}\text { https://www.climateinteractive.org/programs/ } \\
\text { world-climate/ }\end{array}$ \\
\hline World Energy Simulator & $\begin{array}{l}\text { https://www.climateinteractive.org/programs/ } \\
\text { world-energy/ }\end{array}$ \\
\hline World without Oil & https://writerguy.com/wwo/metacontact.htm \\
\hline Worlds Future & $\begin{array}{l}\text { https://systemssolutions.org/portfolio-items/the- } \\
\text { worlds-future-game/ }\end{array}$ \\
\hline
\end{tabular}


List of 24 more sophisticated games from the Reckien and Eisenack [8] article that were not used for the analysis.

\begin{tabular}{l|l}
\hline Name & $\begin{array}{l}\text { Reason for } \\
\text { exclusion }\end{array}$ \\
\hline $\begin{array}{l}\text { A game framework a game framework for scenario generation for the co2 } \\
\text { issue (Robinson \& Ausubel, 1983) }\end{array}$ & $\mathrm{a}$ \\
\hline Aqua-planing & $\mathrm{b}$ \\
\hline CO2-Emissionshandel & $\mathrm{b}$ \\
\hline CO2FX & $\mathrm{b}$ \\
\hline CO2-the interactive negotiation & $\mathrm{a}$ \\
\hline C-ROADS & $\mathrm{a}$ \\
\hline Dynamic Climate Change Simulator & $\mathrm{a}$ \\
\hline Early warning, early action & $\mathrm{a}$ \\
\hline Energiekonferenz & $\mathrm{b}$ \\
\hline Energy City (1) & $\mathrm{b}$ \\
\hline Energy City (2) & $\mathrm{b}$ \\
\hline Frischer Wind in Stahlhausen & $\mathrm{b}$ \\
\hline Greenhouse gas simulator & $\mathrm{a}$ \\
\hline Keep Cool in sunshine city & $\mathrm{b}$ \\
\hline Klimakonferenz Lausitz & $\mathrm{b}$ \\
\hline LogiCity & $\mathrm{b}$ \\
\hline Love letters to the future & $\mathrm{a}$ \\
\hline Planet Green Game & $\mathrm{b}$ \\
\hline Plantville & $\mathrm{b}$ \\
\hline Rizk & $\mathrm{b}$ \\
\hline Strom für Europa! & $\mathrm{b}$ \\
\hline Surfing Global Change: Negotiating Sustainable Solutions & $\mathrm{a}$ \\
\hline The climate challenge & $\mathrm{b}$ \\
\hline Weltklimagipfel & $\mathrm{b}$ \\
\hline Remaks & \\
\hline
\end{tabular}

\section{Remarks:}

a means "the application did not meet the selection criteria for a sophisticated game", b means "not enough information available".

Supplementary Materials: Table S1 "Game Characteristics". 


\section{References}

1. IPCC: Summary for policymakers. In: Field, C.B., Barros, V.R., Dokken, D.J., Mach, K.J., Mastrandrea, M.D., White, L.L. (eds.) Climate Change 2014: Impacts, Adaptation, and Vulnerability. Part A: Global and Sectoral Aspects. Contribution of Working Group II to the Fifth Assessment Report of the Intergovernmental Panel on Climate Change. Cambridge University Press, Cambridge (2014)

2. IPCC: Summary for Policymakers. In: Masson-Delmotte, V., Zhai, P., Pörtner, H.-O., Roberts, D., Skea, J., Waterfield, T. (eds.) Global Warming of $1.5^{\circ} \mathrm{C}$. An IPCC Special Report on the impacts of global warming of $1.5^{\circ} \mathrm{C}$ above pre-industrial levels and related global greenhouse gas emission pathways, in the context of strengthening the global response to the threat of climate change, sustainable development, and efforts to eradicate poverty Geneva. World Meteorological Organization, Switzerland (2018)

3. Schneidewind, U., Wiegandt, K., Welzer, H.: Die Große Transformation: Eine Einführung in die Kunst gesellschaftlichen Wandels: FISCHER E-Books (2018)

4. Moxnes, E., Saysel, A.K.: Misperceptions of global climate change: information policies. Clim. Change 93(1), 15 (2008)

5. Sterman, J., Sweeney, L.B.: Cloudy skies: assessing public understanding of global warming. Syst. Dyn. Rev. 18(2), 207-240 (2002)

6. Sterman, J., et al.: Climate interactive: the C-ROADS climate policy model. Syst. Dyn. Rev. 28(3), 295-305 (2012)

7. Ulrich, M.: Games/simulations about environmental issues - existing tools and underlying concepts. Paper Presented at the 28th Annual Conference of the International Simulation and Gaming Association, Tilburg, The Netherlands (1997)

8. Reckien, D., Eisenack, K.: Climate change gaming on board and screen: a review. Simul. Gaming 44(2-3), 253-271 (2013)

9. Ulrich, M.: Gaming, the language to shape a sustainable future - a journey from 1974 to 2054. In: Duke, R., Kritz, W.C. (eds.) Back to the Future of Gaming. wbv Bertelsmann Verlag, Germany (2014)

10. Duke, R., Geurts, J.: Policy Games for Strategic Management. Pathways into the Unknown. Dutch University Press, Amsterdam (2004)

11. Wenzler, I.: The role of simulation games in transformational change. In: Kritz, W.C. (ed.) Planspiele fur die Organisalionsenfwicklung ed Berlin: WVB (2008)

12. Robinson, J., Ausubel, J.H.: A game framework for scenario generation for the $\mathrm{Co} 2$ issue. Simul. Games 14(3), 317-344 (1983)

13. McGonigal, J.: Reality Is Broken: Why Games Make Us Better and How They Can Change the World. The Penguin Press, New York (2011)

14. d'Aquino, P., Bah, A.: Land policies for climate change adaptation in West Africa: a multilevel companion modeling approach. Simul. Gaming 44(2-3), 391-408 (2013)

15. Lebel, P., Sriyasak, P., Kallayanamitra, C., Duangsuwan, C., Lebel, L.: Learning about climate-related risks: decisions of Northern Thailand fish farmers in a role-playing simulation game. Reg. Environ. Change 16(5), 1481-1494 (2015). https://doi.org/10.1007/ s10113-015-0880-4

16. Valkering, P., van der Brugge, R., Offermans, A., Haasnoot, M., Vreugdenhil, H.: A perspective-based simulation game to explore future pathways of a water-society system under climate change. Simul. Gaming 44(2-3), 366-390 (2013)

17. Feldpausch-Parker, A.M., O’Byrne, M., Endres, D., Peterson, T.R.: The adventures of carbon bond: using a melodramatic game to explain CCS as a mitigation strategy for climate change. Greenhouse Gases: Sci. Technol. 3(1), 21-29 (2013) 
18. Kauneckis, D.L., Auer, M.R.: A simulation of international climate regime formation. Simul. Gaming 44(2-3), 302-327 (2013)

19. Lee, J.J., Ceyhan, P., Jordan-Cooley, W., Sung, W.: GREENIFY: a real-world action game for climate change education. Simul. Gaming 44(2-3), 349-365 (2013)

20. Matzner, N., Herrenbrück, R.: Simulating a climate engineering crisis: climate politics simulated by students in model United Nations. Simul. Gaming 48(2), 268-290 (2017)

Open Access This chapter is licensed under the terms of the Creative Commons Attribution 4.0 International License (http://creativecommons.org/licenses/by/4.0/), which permits use, sharing, adaptation, distribution and reproduction in any medium or format, as long as you give appropriate credit to the original author(s) and the source, provide a link to the Creative Commons license and indicate if changes were made.

The images or other third party material in this chapter are included in the chapter's Creative Commons license, unless indicated otherwise in a credit line to the material. If material is not included in the chapter's Creative Commons license and your intended use is not permitted by statutory regulation or exceeds the permitted use, you will need to obtain permission directly from the copyright holder.

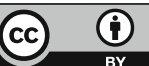

